\title{
Transport Choices and Tourism Destination Competitiveness: The Case of Zimbabwe
}

\author{
Shepherd Nyaruwata (Corresponding author) \\ University of Zimbabwe: Tourism, Leisure and Hospitality Studies Department \\ P Bag MP 167 Mount Pleasant, Harare, Zimbabwe \\ Tel: 263-772-686-165Ｅ-mail: scnyaruwata@gmail.com
}

\begin{abstract}
Douglas Runyowa
Ministry of Tourism and Hospitality Industry: Research and Planning Department

Cnr Innez Terrece/Speke Avenue, Harare, Zimbabwe

Tel: 263-477-5402Ｅ-mail: rundoug7@yahoo.com
\end{abstract}

Received: June 25, 2017 Accepted: August 18, 2017

doi:10.5296/ber.v7i2.12000ＵRL: https://doi.org/10.5296/ber.v7i2.12000

\begin{abstract}
The tourism industry in Zimbabwe has experienced fluctuating trends in its growth since the dawn of the new millennium. The Ministry of Tourism and Hospitality Industry undertook a visitor exit survey in 2015/2016 period. The purpose of the study was to gather visitors' views on Zimbabwe as a tourist destination in order to guide policy formulation on the sector. One of the objectives of the survey was to assess the visitor perceptions of Zimbabwe as a competitive tourist destination. Questionnaires were administered to departing visitors at the country's three international airports and seven border posts during the period July 2015 until June 2016. The results of the survey indicated that $77 \%$ of visitors use road transport to enter into the country. The survey also showed that $18 \%$ of visitors to the country travelled by air. It is recommended that that the government accelerates the implementation of the open skies policy so as to attract more direct international airlines to fly into the country. It is also recommended that the government undertakes massive improvement of the road infrastructure in the country so as to encourage the geographical distribution of tourists within the country. It is finally recommended that the private sector and the national tourist organization, Zimbabwe Tourist Authority (ZTA) engage international tour operators and persuade them to develop and promote fly-drive tour packages to the country.
\end{abstract}


Keywords: Tourism, Transport, Infrastructure, Accessibility

\section{Introduction}

In most destinations, transport plays a critical role for the success of the tourism sector. It provides the umbilical cord that binds tourism destinations and their source markets and also ensures that tourists can be dispersed geographically within a destination. In terms of planning for tourism growth, a two pronged approach is therefore essential, to ensure that a destination is linked with source markets which mostly is by air transport and also to ensure internal destination accessibility through air, rail and road transport. Internal accessibility makes it easier for tourists to travel within a destination. Zimbabwe carried out its $5^{\text {th }}$ Visitor Exit Survey from June 2015 until July 2016. One of the issues that feedback was provided by tourists was on the mode of transport they used to enter and exit Zimbabwe and also during their stay in the country. The paper analyses the results of the survey and their implications on tourism and transport planning in Zimbabwe and provides recommendations to improve the destination's external and internal access for tourists to the country.

\section{Literature Review}

Most of the literature reviewed acknowledges transport as a significant pillar in the development of tourism in any destination (Lohmann, 2003). Many authors have attempted to describe the phenomenon of travel and tourism as a system. Classical views in this regard include the Tourism Systems Approach developed by Leiper (1989), which identifies that any travel builds from a tourist generating region from where a tourist departs through a route to a destination of choice and then travels back again. This theory by Leper (1989), is depicted in Figure 1 below:-

\section{Transit region or route}

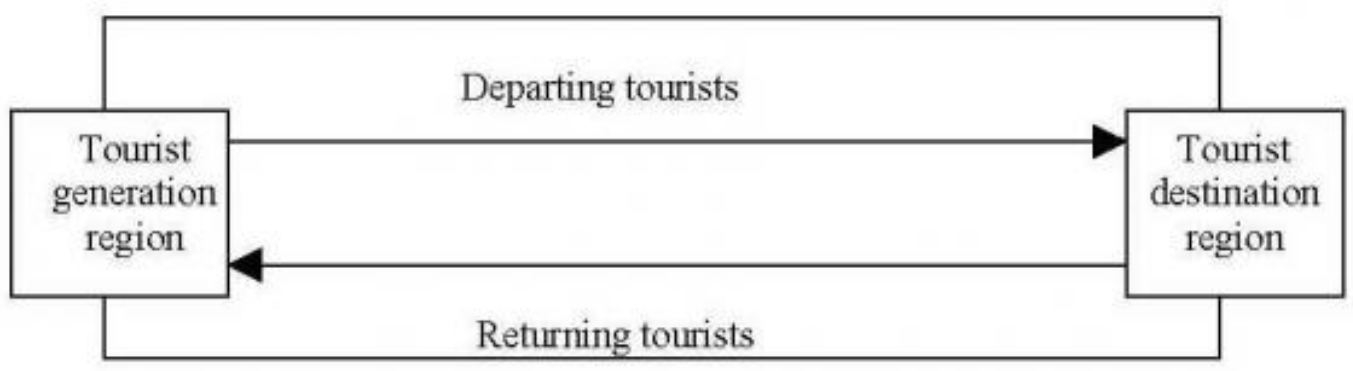

Transit region or route

Source: Leiper, 1989.

Figure 1. Leipers tourism Systems Theory

Following the work of Leiper, several other researchers have built on this theory which focuses on the accessibility of a destination, with regard to entry and exit. Jing et al (2008), has coined the term, "destination based accessibility", to refer to the ease with which one arrives at a point from a certain area within the same destination. This therefore means that a destination apart from ensuring that it is linked with its source markets well regionally and 
internationally, should endeavour to promote internal accessibility. Seethanah and Khadaroo (2007) postulates that the growth of tourism in Mauritius in the eighties and nineties was aided by the internal development of transport infrastructure in the country as well as the development of competitive international air accessibility to the destination. Similar views are expressed by Kim et al (2001) who concluded that the growth of Sun City resort in South Africa received great impetus from the provision of adequate transport infrastructure by government.

Musa \& Ndawayo (2011) reviewed arguments that have been put forward by different authours on the role that transport has played in facilitating tourism development. They concluded from their study of the development of tourism in national parks in Nigeria that transport linkages were critical in the growth of tourism in the different national parks in the Nigeria.

There are a number of cases studies where national or regional governments have developed transport systems with an objective of opening up remote rural areas for tourism development. For example the European Union's ERDF programme has focussed on transport development so as to facilitate the dispersal of tourists into rural areas and at the same time stimulate economic development in rural destinations (2015).

One of the key competitive factors in tourism has been found to be accessibility of the destination through both road and air transport systems (WEF 2016). Therefore in order for a destination to thrive it is important to ensure that both external and internal transport system are adequately developed. The entry and exit ports to the country need to be efficiently managed so that the tourists gain a positive impression of the destination at entry and depart the destination with the same positive impression.

\section{Methodology}

The data used in the paper was obtained from the findings of the $5^{\text {th }}$ Visitor Exit survey which was undertaken in Zimbabwe from July 2015 until June 2016. Data for the survey was collected using a questionnaire administered to a sample of 34000 tourists that visited Zimbabwe between June 2015 until July 2016 who were the survey population. A response rate of $89.2 \%$ was achieved. The questionnaire was pre-tested in Bulawayo at the airport and in Plumtree at the border post from $15^{\text {th }}$ to $19^{\text {th }}$ June 2015. Adjustments were made to the wording and structure of the questionnaire in view of the results of the pre-testing process. The sample was stratified by ports of exit to ensure proper presentation of the country's source markets. Systematic random sampling was used to select the respondents at each border post. The appeal of systematic sampling is highlighted by Elsayir (2014), who believes that it is spread more evenly over the entire population than a stratified sample where the strata are drawn separately.

Questionnaires were administered to departing visitors at the country's three main airports of; Harare International airport, Victoria Falls International airport and the Joshua Mqabuko Nkomo International airport. Further, questionnaires were administered to departing visitors at the border posts of Beitbridge, Chirundu, Victoria Falls, Forbes, Nyamapanda, Kazungula 
and Plumtree.

The one year period allowed the survey to take care of seasonality of the tourism business. Marshall et al (2006), argue that a survey research is the most appropriate inquiry to make inferences about a large group based on a small number. In other words it allows for generalisation of findings.

Data entry into the computer was done using the Census and Survey Processing System (CSPro) software Version 6.2 (VES: 6). Data were analysed using the Statistical Analysis System (SAS) software Version 9.3 (ibid).

\section{Presentation of Findings}

The data obtained from the survey brought up a number of interesting facts on the travel preferences of tourists with regards to modes of transport into and around the country. Figure 2 shows the mode of transport used to enter into the country.

\subsection{Modes of Transport Used to Enter into Zimbabwe}

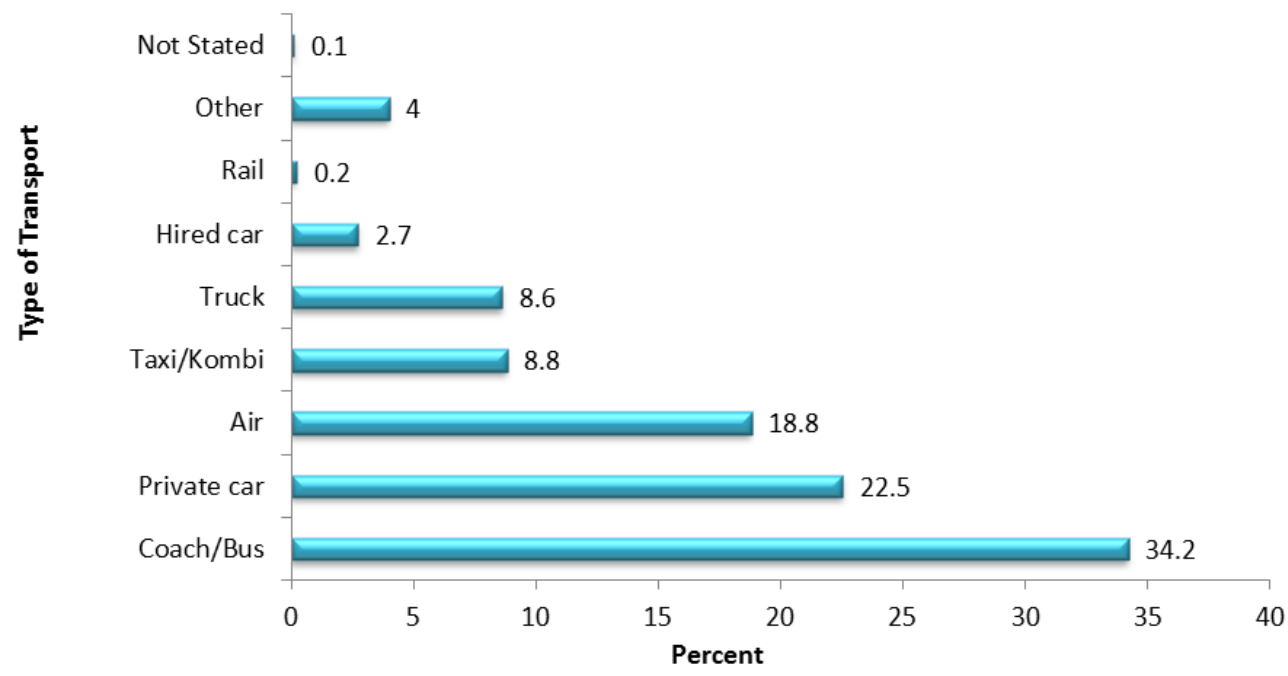

Figure 2. Type of Transport used to enter the country, VES2015/16

\section{Source: Zimstat VES/2015/16}

Figure 2 shows that the largest number of visitors (34.2\%) used coach /bus transport to enter into the country followed by the private car $(22.5 \%)$ and then air transport $(18.8 \%)$. The outcome of the survey was in line with the overall trends of tourists arrivals to the country over a long period of time (ZTA, 2000-2015). The majority of foreign tourists to Zimbabwe in any given year are regional tourists most of whom travel by road, for example in 2006, 70\% of the visitors to the country travelled by road whilst air transport was used by $9.5 \%$ of the visitors (ZTA, 2007). The figure further reveals that rail transport was used by only .2\% of tourists to the country. This is despite the fact that Zimbabwe is connected by rail to all of its neighbouring countries. Further the railway system is at the centre of the international rail routes linking the DRC and Zambia to Botswana, Mozambique and its ports, and South Africa and its ports. 
The paucity of travellers using rail transport to enter into Zimbabwe is a reflection of the dilapidated state of the infrastructure which has resulted in some major accidents and derailments in recent years (African Development Bank, 2011). The bank report indicated that only about $29 \%$ of the rail rolling stock is still in good condition and that the National Railways of Zimbabwe is facing serious shortages of locomotives, wagons and coaches. The NRZ is teetering on the brink of collapse, weighed down by debts and obsolete equipment. The poor state of the rail infrastructure has therefore meant that travellers to the country have had to use other forms of transport to enter into Zimbabwe.

In the past the rail infrastructure was used by special tourists' trains like Blue Train to bring visitors into the country. The governments is desirous of resuscitating the rail infrastructure in order that it becomes a key component of transport used by tourists to enter into Zimbabwe. The Zimbabwe government in 2014 indicated that it had secured a $\$ 750$ million loan from Development Bank of South Africa to rehabilitate the rail network and locomotives (The Chronicle, 2014). The funds were earmarked for track relaying, refurbishing signaling equipment and the purchase of new locomotives. The government has further pronounced its interests in attracting private investment in National Railways of Zimbabwe (NRZ).

The smaller percentage of people entering the country using hired cars $(2.7 \%)$ mirrored the challenges that Zimbabwe and other countries have had in promoting seamless tours across national borders. Given the central location of Zimbabwe within the Southern African Development Community region (SADC) it would have been expected that a higher number of tourists would have used this mode of transport from South Africa, Botswana and Zambia. Further, the fact that Zimbabwe uses the US\$ makes local car hire less competitive compared to paying for the vehicles in neighbouring countries. Permit systems, multiplicity of licences and taxes at entry points has made Zimbabwe unattractive for tourists to travel using vehicles hired in other countries. The challenges were also highlighted in the regional study of RETOSA (2012) which recommended among other things the need to liberalize port of entry regulations at border posts. A number of countries in the region have since then implemented measures that have improved entry and exit of visitors, for example South Africa. However this has not been the case in Zimbabwe. The problem in Zimbabwe has been exacerbated by the bureaucracy that is encountered at border posts like Beit Bridge and Chirundu where corruption is also rife.

\subsection{Modes of Transport Used Internally}

The survey also captured the modes of transport used by tourists to travel within the country. Figure 3 below shows the type of transport which was utilized by visitors during their stay in the country. 
Type of Transport Used Within the country,VES 2015/16

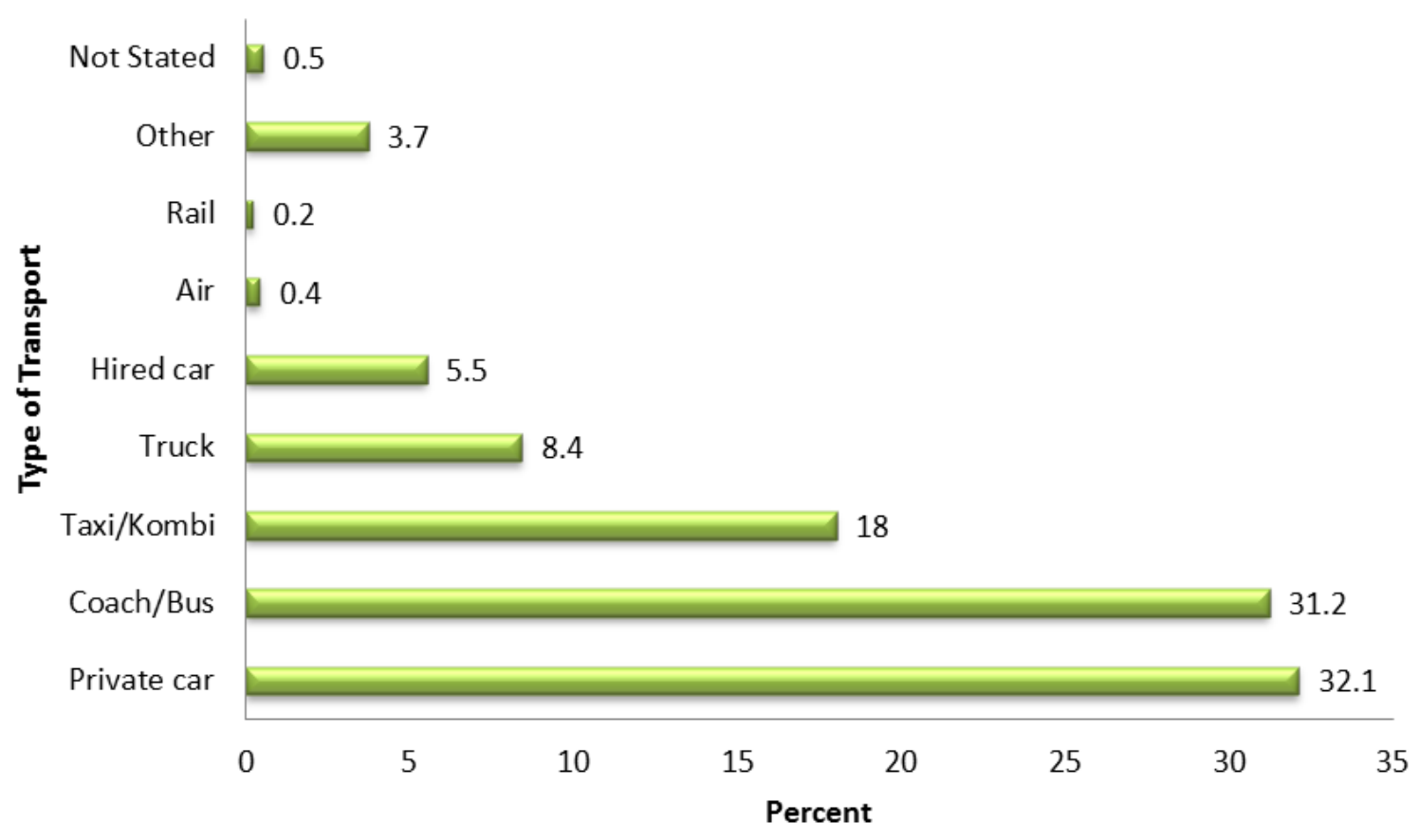

Figure 3. modes of transport used to travel within the country: Source: VES 2015/2016

\subsubsection{Road Transport Usage}

The most common mode of transport used by the visitors was private car $(32.1 \%)$ which was followed by use of coach/bus (31.2\%). A significant proportion of the visitors (18\%) used taxis/kombis in travelling around the country. The use of hired cars was limited to a mere 5.5\% of the sampled visitors. Overall $95 \%$ of the visitors to the country used one form or another of road transport.

While Zimbabwe boasts one of the most extensive road networks in the Southern African Development Region (SADC) region, its condition has deteriorated rapidly over the past two decades. As of 2008 Zimbabwe had one of the lowest percentages of roads in good condition in the region and this position has not changed (New Zimbabwe, 2015). Whilst the government has made some efforts in improving the country's road infrastructure more needs to be done in order to enable tourists to explore different parts of the country without being hindered by poor road networks.

Given the proliferation of the use the internet globally it is most likely that a number of individuals are offering their vehicle for hire on different platforms to the international market. The rates offered by individuals will be far more competitive than those offered by established car hire companies. The government therefore needs to investigate this phenomenon and make sure that those hiring out their vehicles privately are properly licensed and insured lest the image of the country could be compromised.

\subsubsection{Air Transport Usage}

A striking result of the survey is the fact that the usage of air transport by tourists within the 
destination was less than $1 \%$ (VES: 16). The results initially look surprising given that the country has three major international airports, namely, Harare International Airport, Joshua Mqabuko Nkomo International Airport in Bulawayo and the Victoria Falls International Airport. Further Zimbabwe has a number of functional domestic airports which include among others Buffalo Range Airport in Chiredzi, Masvingo Airport, in Masvingo city, Kariba Airport in Kariba resort town and Hwange airport in Hwange National park.

The lack of use of air transport for internal movements of tourists is due to a number of factors. Firstly, the national airline due to operational challenges and lack of market viability discontinued to service the tourist route of Harare/Kariba/ Hwange /Victoria Falls. Local and international tour operators therefore stopped packaging the route in their holiday packages. Individual tourists who wished to visit these areas could only do so using road transport. Similarly, the national airline in 2012 stopped its scheduled flights to Victoria Falls for a period of six months due to operational challenges. Although the scheduled flights were resumed later in 2013 both the domestic and international market lost confidence on the reliability of the Air Zimbabwe. The introduction of a new airline, Fastjet on the Harare /Victoria Falls route helped to ameliorate the problem and galvanized Air Zimbabwe to reposition itself more effectively due to fear of losing market share to the new airline. The implementation of the open skies policy by government has encouraged new airlines to apply for licences to service the domestic market and compete with Air Zimbabwe. The open skies policy has also attracted a number of new airlines to fly into the country, for example the Emirates Airline and Air Ruanda.

Secondly the national airline stopped flying to second tier airports like Buffalo Range and Masvingo almost two decades ago. These destinations have therefore not been featured on the tour itineraries of international tour operators. Tourists wishing to visit these destinations have either to hire private aircrafts or use road transport. Finally Zimbabwe has over the past ten years concentrated on promoting Victoria Falls as the key destination in the country with the result that most international tourists buy multi-country tour packages which include only Victoria Falls in Zimbabwe. There is therefore very low demand for destinations like Kariba and Masvingo in the international market. Private airlines that have attempted to build up demand for the Kariba /Hwange Victoria Falls have found it difficult to sustain their efforts and hence had to pull out of the route.

Lack of internal air connectivity helps to explain the lack of geographical distribution of tourists in the country. Destinations like Masvingo and the Eastern Highlands are too far away from the country's icon tourist's attraction, Victoria Falls, to be included in a fly drive tour package. Most tourists do not have the time to drive the long distances that are involved to reach these areas. The issue also brings into focus the debate on the adoption of the open skies policy in line with the Yamoussoukro Declaration. On the one hand the government needs to implement the agreement to which it is a signatory, on the other hand it is seized with the need to protect the national airline which faces collapse if exposed to the full competition of the open skies policy. This is because over the last five years, except for Faster Jet and Rainbow Airlines, lucrative routes such as Harare-Victoria Falls and Harare Bulawayo appear to have been a preserve of Air Zimbabwe regardless of its operational 
challenges. When this policy position and the challenges affecting the viability of Air Zimbabwe are read with the low utilisation of the airline as a mode of transport within the destination it places focus on the dual need for either a policy shift or a serious need to capacitate Air Zimbabwe. The airline is operating with a depleted fleet and would need smaller aircrafts to ply domestic routes.

\subsubsection{Transport Used on Departure}

The modes of transport used to depart Zimbabwe were not very different from the modes of transport used to enter the country. The substantive difference was that whilst $32.1 \%$ of the visitors arrived into the country using the private car, only $22 \%$ departed using the same mode of transport. The air transport usage to enter and depart the country remained the same indicating that most tourists purchase round trips on their visit to Zimbabwe.

\section{Conclusion}

The majority of regional tourists to Zimbabwe use road transport to enter into the country. Direct international air accessibility is limited with the majority of visitors to the country using Johanesburg in South Africa as the gateway to the country. Further, visitors to Zimbabwe mainly use road transport to travel to different destinations in the country which has resulted in internal air transport route circuits being unviable.

\section{Recommendations}

The government needs to accelerate the implementation of the open skies policy so as to attract more direct international airlines to fly into the country. This will help in the marketing and promotion Zimbabwe as a tourists destination and hence increase tourist arrivals.

The government should undertake massive improvement of the road infrastructure in the country so as to encourage the geographical distribution of tourists within the country. The commencement of the dualization of the Beitbridge -Chirundu highway (2017) was a step in the right direction. But this must be complemented by streamlining of the police road blocks on the road and the improvement of processing of visitor entry at both Beitbridge and Chirundu border posts.

The private sector and the national tourist organization, Zimbabwe Tourist Authority (ZTA) should engage international tour operators and persuade them to develop and promote fly-drive tour packages to the country. This will facilitate the spreading of economic benefits of tourism to the rest of the country.

The government needs to seek partners to work with in modernizing the rail transport infrastructure which in both developed and developing countries is a very popular mode of transport for internal movement of tourists.

\section{References}

AfDB (2011). Road Transport Services and Infrastructure Zimbabwe Report. Retrieved March 20th, 2017 from; 


\section{Macrothink}

Business and Economic Research ISSN 2162-4860 2017, Vol. 7, No. 2

http://www.afdb.org/fileadmin/uploads/afdb/Documents/Generic-Documents/11.\%20Zimbab we\%20Report_Chapter\%209.pdf

Elsayir, A. H. (2014). Comparison of precision of probability sampling with other probability samplings. American Journal of Theoretical and Applied Statistics, 3(4), 111-116. https://doi.org/10.11648/j.ajtas.20140304.16

Kim, L., Crompton, J., \& Botha, P. (2000). Responding to competition: A strategy for Sun/Lost City; South Africa: Tourism Management, 21, 33-41. https://doi.org/10.1016/S0261-5177(99)00094-1

Leiper, N. (1989). Tourism and tourism systems, Occasional paper: No.1, Department of Management Systems, Massey University, Palmerston North, New Zealand.

Lohmann, G. (2003). The role of transport in tourism development: nodal functions and management practices. Retrieved June 6th, 2017 from

www.research-repository.griffith.edu.au

Marshall, C., \& Rossmann, G. B. (2006). Designing Qualitative Research (4 ${ }^{\text {th }}$ edition). London, England. Sage Publications.

Musa, I. J., \& Ndawayo, B. A (2011). The role of transport in development of tourism in Nigeria. Retrieved May $3^{\text {rd }} 2017$ from www.chios.aegean.gr/Tourismo vol 6-no1/art17 pdf pp297-305

New Zimbabwe (2015). Poor infrastructure costing Zimbabwe \$1bln annually, saysAfDB. Retrieved: April $7^{\text {th }} 2017$ from

http://www.newzimbabwe.com/business-23249-Poor+infrastructure+costs+Zim+\$1bln,+AfD B/business.aspx

Seethanah \& Khadaroo (2007). Transport infrastructure and tourism development: Annals of tourism Research, 34(4), 1021-1032. https://doi.org/10.1016/j.annals.2007.05.010

The Chronicle, Staff reporter (26 November, 2014). National Railways of Zimbabwe gets $\$ 750$ million. Retrieved May $2^{\text {nd }} 2017$ from www.chronicle.co.zw

World Bank, (2008a). Zimbabwe Infrastructure Dialogue in Roads, Railways, Water, Energy and Telecommunication Sub-sector, Report no 43855-ZW: Retrieved May12th 2017 from www.documents.worldbank.org

World Economic Forum (2017). Global Competitive Report 2016. RetrievedMay20th from www.3weforum.org/doc

Zimstat (2017). Zimbabwe Visitor Exit Survey (VES) Report 2015/1

Zimbabwe tourist Authority (2008). Annual report 2009

Zimbabwe Tourist Authority (2000-2016). Annual reports 2001-2016. 


\section{Copyright Disclaimer}

Copyright for this article is retained by the author(s), with first publication rights granted to the journal.

This is an open-access article distributed under the terms and conditions of the Creative Commons Attribution license (http://creativecommons.org/licenses/by/3.0/). 